\title{
CLINICAL-EPIDEMIOLOGICAL PROFILE OF HOSPITALISED PATIENTS IN PAEDIATRIC INTENSIVE CARE UNIT
}

\author{
Naycka Onofre Witt Batista 1,3, Maria Carlota de Rezende Coelho', Silvia Moreira Trugilho', ${ }^{1,2}$ \\ Gustavo Carreiro Pinasco ${ }^{3}$, Edige Felipe de Sousa Santos ${ }^{3,4}$, Valmin Ramos-Silva ${ }^{1,2}$
}

\begin{abstract}
Introduction: Paediatric intensive care units have made important advances in technology and assistance since the 1980s, which have made more favourable the prognosis of critically ill children all over the world. Objective: Identify the epidemiological profile and clinical outcomes of hospitalised children and adolescents in the Paediatric Intensive Care Unit of Hospital Vitória, Espirito Santo, Brazil. Methods: A descriptive and retrospective study carried out in the Paediatric Intensive Care Unit of Hospital Infantil Nossa Senhora da Glória in the city of Vitória, Espirito Santo, Brazil. Age, sex, hospitalisation diagnosis, progression to discharge/death, and length of hospital admission were obtained from the Sector of Medical and Hospital Statistics Files between 2011 and 2012. For the descriptive analysis, categorical variables were expressed as absolute and percentage, and the continuous variables in average and standard deviation. For comparison, Pearson's chi-squared tests, Fisher's test, and Student's t test were used and $p$ values $<0.05$ with confidence interval of $95 \%$ were considered statistically significant. Results: Of the 609 patients analysed, $342(56.2 \%)$ were male (mean age: $72.7 \pm 71.3$ months). Respiratory disease, postoperative processes, and trauma were the main causes of hospitalisation. The average duration of hospitalization was $6.9 \pm 5.5$ days; 514 (84.4\%) patients were discharged, 95 (15.6\%) died, and of those, $53(55.7 \%)$ died in less than 72 hours of hospitalisation. Conclusion: Most of the patients were less than 2 years of age. The leading causes of hospitalisation were respiratory disease (pneumonia, bronchiolitis, and asthma), sepsis, and head injury, which was the major cause of the trauma motivated by violence. The average hospital admission in the unit was one week and the mortality rate was $15.6 \%$, with one third of the deaths recorded in the first 72 hours of hospitalisation.
\end{abstract}

Key words: pediatric intensive care units, health profile, child.

\section{INTRODUCTION}

A seriously ill child faces a condition of severe dysfunction of one or more organ systems, which, if not treated in an early and effective way, significantly increases the risk of after-effects and death. Paediatric intensive care units (PICU) attend to patients aged from 29 days to 18 years uncompleted. In some hospitals, the maximum age accepted is 14 years old.

The improvement of specialised care for seriously ill children began in 1980 and the number of these units growth throughout the world. This contributed to increase investments in technology and research, resulting in the production of new equipment and drugs for life support. Increasing the demand of production and implementation of clinical protocols, undoubtedly contributed to the reduction of infant mortality from $15 \%-20 \%$ to $3 \%-10 \%$ in PICUs, between 1980 and $1990^{1}$.

The prognosis of a child in critical condition in the PICU are influenced by intrinsic factors to the patient, such as pre-existing comorbidities, clinical severity on admission, and age. Furthermore, there is the influence of factors

1 Programa de Pós-Graduação. Mestrado em Políticas Públicas e Desenvolvimento. Escola Superior de Ciências da Santa Casa de Misericórdia de Vitória (EMESCAM), Vitória (ES), Brasil.

2 Programa de Residência Médica em Pediatria - Hospital Estadual Infantil Nossa Senhora da Glória, Vitória (ES) Brasil.

3 Laboratório de Delineamento de Estudos e Escrita Científica. Faculdade de Medicina do ABC, Santo André, SP.

4 Docente da Faculdade Leão Sampaio. Juazeiro do Norte, CE, Brasil.

Corresponding author: Valmin Ramos-Silva. E-mail: valmin.ramos@emescam.br

Suggested citation: Batista NOW, Coelho MCR,Trugilho SM, Pinasco GC, Santos EFSS, Ramos-Silva V. Clinical-epidemiological profile of hospitalised patients in paediatric intensive care unit. Journal of Human Growth and Development. 25(2): 187-193. DOI: http://dx.doi.org/10.7322/jhgd.103014

Manuscript submitted: apr 22 2015. Accepted for publication aug 102015. 
related to the experience of the care team, health assistance, the availability of material resources, and the use of clinical care protocols, among others. In addition, the knowledge of the clinical and epidemiological profile of critically ill children is of fundamental importance for the planning of health actions that are able to mitigate the various factors related to the evolution of a critically ill child seen in these sectors ${ }^{2}$.

High-quality health services are guided by indicators of morbidity and mortality and their direct association to the assisted age groups. Studies characterising the assisted population at the tertiary level may be able to induce improvements in the quality of child health care, including at primary level, where prevention and treatment remain not so effective ${ }^{3}$.

The inadequacies of the public health services in the country, mostly in primary care, contribute to overload in the tertiary health sector, including paediatric intensive care. This is due to low funding in the sector, the changing epidemiological profile of causes of death in childhood, and the distrust of the population on health prevention and promotion program mes $^{4}$. The objective of this study is to identify the epidemiology and clinical outcome of children and adolescents hospitalised in the PICU in Vitória, Espirito Santo, Brazil.

\section{METHODS}

Descriptive and retrospective study conducted at the PICU of Hospital Infantil Nossa Senhora da Glória (HINSG), Vitória, Espirito Santo, Brazil.

HINSG has 133 beds for surgical and medical admissions in the various paediatric subspecialties and is the reference for paediatrics in Espirito Santo state, with attendance in secondary and tertiary care in children's and adolescent's health. It is a reference for the Metropolitan Region of Grande Vitória and for other municipalities of Espirito Santo, as well as for some places of other states such as Bahia, Minas Gerais, and Rio de Janeiro, Brazil.

The PICU/HINSG was restructured in 1986 and has six beds for hospitalisation of children older than 28 days until 18 years old. Assistance is provided by a multidisciplinary team of paediatric critical care physicians, nurses and nursing technicians, physical therapists, social workers, psychologists, dietitians, speech therapists, and doctors specialised in the field of paediatrics.

The study population consisted of all patients admitted to the PICU at HINSG, Vitória, Espirito Santo, Brazil, between January 2011 and December 2012.

Data were obtained from the Registration Section at the Medical and Hospital Statistics File. The variables related to age, gender, diagnosis, hospitalisation and prognosis to discharge or death, and length of hospital admittance in the PICU and in the wards after discharge from the PICU were organised and analysed using SPSS 11.0 software. For age analysis, we adopted the following stratification proposed by the Brazilian Society of Paediatrics ${ }^{5}$ : infants ( 29 days to 24 months incomplete), preschool and school (25-120 incomplete months), and adolescents ( $\leq 120$ days).

For the descriptive data analysis, categorical variables were expressed as absolute and percentage frequencies. Continuous variables were expressed as average and standard deviation. For comparisons, when indicated we used Pearson's chisquare, Fisher's exact test, the Student test, and ANOVA test, with $p$ values $<0.05$ being considered statistically significant, with and a confidence interval of $95 \%$. Ethics Committee Approval 12328313.5.0000.5065.

\section{RESULTS AND DISCUSSION}

In the years 2011 and 2012, 609 patients were admitted to the PICU/HINSG: 342 (56.2\%) male and 267 (43.8\%) female. The monthly average hospital admission was 25 patients, and the average hospitalisation was $6.9 \pm 5.5$ days. Most patients were infants of 24 months (272 / 44.7\%), followed by adolescents (164 / $26.9 \%$ ) and pre-school and schoolchildren (173/28.4\%), as indicated in Table 1.

The average age for the males was $72.7 \pm$ 71.3 months and for the females $66.5 \pm 60.1$ months, while the average length of hospital admission for the males was $7.4 \pm 5.8$ days and for the females $6.3 \pm 5.1$ days $(p=0.014)$.

Regarding clinical outcome, 514 (84.4\%) patients were discharged from the unit and 95 $(15.6 \%)$ died. For the hospitalisation and the progression to death, there were found 20 (21\%) deaths among patients with length of hospital admittance $\leq 24$ hours. In relation to age group, $35.8 \%$ (34) of deaths occurred in infants (1-24 months) (Table 1 ).

The same patient may have presented several clinical diagnoses and complications involving multiple organs and organic systems. Respiratory diseases were diagnosed in 239 patients (Table 2 ) from which 13 cases had the acute respiratory distress syndrome (ARDS) as a complication, and 20 cases had pleural effusion, 5 in children under 1 year old and 10 cases between 1 and 5 years of age. Diagnostics or less frequent hospitalisation indications were convulsions (14), renal (12) and liver (3) failure, dengue (5), encephalitis (3), hydrocephalus (4), and neuromuscular diseases (4).

Ninety-four patients were hospitalised due to trauma, including head injury (58) and multiple traumas (36). Eighteen of these patients have had firearm injury, 5 had an abdominal injury, 4 drowned, 3 were stung by scorpions, 2 were burned, and the other patients were admitted for other reasons. The trauma by firearms was observed in a 3-year-old, and other 17 cases in adolescents over 10 years. The main diagnoses, according to the stratification by age group and development for discharge and death, are summarised in Table 2. 
Table 1: Clinical outcome of patients admitted to the PICU/HINSG to discharge and death according to age and sex in the years 2011 and 2012

\begin{tabular}{|c|c|c|c|c|c|c|c|c|}
\hline Variables & \multicolumn{7}{|c|}{ Age (months) } & \multirow[t]{3}{*}{ Total (\%) } \\
\hline & 1 to 12 & 13 to 24 & 25 to 36 & 37 to 48 & 49 to 60 & 61 to 120 & $>120$ & \\
\hline \multicolumn{8}{|c|}{ Evolution to discharge } & \\
\hline - Male & 98 & 30 & 15 & 16 & 8 & 35 & 86 & $288(56 \%)$ \\
\hline - Female & 80 & 30 & 17 & 3 & 10 & 33 & 53 & $226(44 \%)$ \\
\hline Total & 178 & 60 & 32 & 19 & 18 & 68 & 139 & $514(100 \%)$ \\
\hline \multicolumn{9}{|c|}{ 2. Hospital admission } \\
\hline - 1 day & 10 & 5 & 4 & 2 & 4 & 3 & 19 & $47(9.2 \%)$ \\
\hline - 2 to 3 days & 23 & 8 & 6 & 4 & 4 & 22 & 27 & $94(18.3 \%)$ \\
\hline-4 to 9 days & 92 & 32 & 13 & 11 & 8 & 31 & 64 & $251(48.4 \%)$ \\
\hline - 10 to 46 days & 53 & 15 & 9 & 2 & 2 & 12 & 29 & $122(23.7 \%)$ \\
\hline Total & 178 & 60 & 32 & 19 & 18 & 68 & 139 & $514(100.0 \%)$ \\
\hline \multirow{2}{*}{\multicolumn{9}{|c|}{ Evolution to death }} \\
\hline & & & & & & & & \\
\hline - Male & 14 & 4 & 4 & 4 & 2 & 15 & 11 & $54(56.9 \%)$ \\
\hline - Female & 13 & 3 & 2 & 3 & 1 & 5 & 14 & $41(43.1 \%)$ \\
\hline Total & 27 & 7 & 6 & 7 & 3 & 20 & 25 & $95(100 \%)$ \\
\hline \multicolumn{9}{|c|}{ 2.Hospital admission } \\
\hline - 1 day & 6 & 1 & 0 & 2 & 0 & 4 & 7 & $20(21.0 \%)$ \\
\hline - 2 to 3 days & 5 & 2 & 0 & 0 & 0 & 3 & 3 & $13(13.7 \%)$ \\
\hline - 4 to 9 days & 11 & 2 & 3 & 3 & 2 & 8 & 9 & $38(40.0 \%)$ \\
\hline - 10 to 36 days & 5 & 2 & 3 & 2 & 1 & 5 & 6 & $24(25.3 \%)$ \\
\hline Total & 27 & 7 & 6 & $\overline{7}$ & 3 & 20 & 25 & $95(100.0 \%)$ \\
\hline
\end{tabular}

Table 2: Diagnoses of patients admitted to the PICU/HINSG between 2011 and 2012 according to age and progression to discharge or death

\begin{tabular}{|c|c|c|c|c|c|c|c|c|c|}
\hline \multirow[t]{2}{*}{ Diagnose } & \multicolumn{7}{|c|}{ Age (months) } & \multicolumn{2}{|c|}{ Evoultion } \\
\hline & $1-12$ & $13-24$ & $25-36$ & $37-48$ & 49-60 & $61-12$ & $>120$ & Discharge & Death \\
\hline Sepsis & 77 & 20 & 17 & 6 & 5 & 24 & 42 & 129 & 62 \\
\hline Pneumonia & 93 & 26 & 16 & 3 & 7 & 16 & 13 & 151 & 23 \\
\hline Bronchiolitis & 44 & - & - & - & - & - & - & 42 & 2 \\
\hline Asthma & 4 & 9 & 2 & 1 & 2 & 1 & 2 & 20 & 1 \\
\hline Congenital hearth desease & 25 & 2 & 1 & 1 & 1 & 3 & 1 & 28 & 6 \\
\hline Cancer & 1 & 4 & 4 & 2 & - & 11 & 17 & 19 & 20 \\
\hline Contagious deseases & 14 & 2 & 2 & - & - & - & - & 15 & 3 \\
\hline Metabolism errors & 4 & 1 & 3 & 1 & - & 7 & 3 & 12 & 7 \\
\hline Meningitis & 3 & 1 & - & - & - & 4 & 3 & 8 & 3 \\
\hline AIDS & 6 & 2 & 3 & - & - & 2 & 4 & 11 & 6 \\
\hline Head trauma & 4 & 4 & 3 & 5 & 5 & 10 & 27 & 52 & 6 \\
\hline Politrauma and General tra & ma- & 3 & 2 & 3 & 1 & 6 & 21 & 34 & 2 \\
\hline
\end{tabular}

The reason for admission to post-operative care was diagnosed in 149 cases involving abdominal (28), head and neck (3), cardiac (14), neurological (50), orthopaedic (25), and thoracic (29) surgeries. Neurological surgery was more frequent in patients over the age of 5 years old, with 15 cases between 5 and 10 years old and 18 cases in adolescents over 10 years old. Six cases of orthopaedic surgery were performed on children aged between 5 and 10 years old and
19 cases over 10 years old. Thoracic surgery was divided into 20 cases in children under 5 years old and 9 cases over 5 years old.

The same patient also may have been affected to a greater or lesser degree in the various organs or organic systems that contributed to the hospitalisation or prolonged hospitalisation maintenance in the PICU. The respiratory system was the most affected, followed by the cardiovascular and nervous systems (Table 3 ).

Table 3: Main affected organs and systems of patients admitted to the PICU/HINSG between 2011 and 2012.

$\begin{array}{lccccc}\text { Age (months) } & \text { Respiratory } & \text { Cardiovascular } & \text { Organ or system } \\ & \text { Nervous } & \text { Renal } & \text { Digestive } \\ 1 \text { to } 12 \text { months } & 197 & 88 & 62 & 7 & 3 \\ 13 \text { to } 24 \text { months } & 66 & 23 & 35 & 1 & 3 \\ 25 \text { to } 36 \text { months } & 35 & 13 & 16 & 0 & 1 \\ 37 \text { to } 48 \text { months } & 25 & 13 & 14 & 0 & 4 \\ 49 \text { to } 60 \text { months } & 18 & 12 & 10 & 5 & 0 \\ 61 \text { to } 120 \text { months } & 81 & 44 & 51 & 12 & 5 \\ >120 \text { months } & 141 & 76 & 261 & 25 & 7 \\ \text { Total } & 558 & 269 & & 28\end{array}$


For the most prevalent diseases, the length of hospitalisation from admission to the discharge was also evaluated. Among the most commonly diagnoses in paediatric patients, the median of 22 days of hospitalisation was observed for patients with pneumonia and 33 days for patients admitted due to sepsis. The average hospitalisation due to external causes was 19 days, and the most frequent injuries were caused by firearm bullets, falls, fractures, injuries, trauma, and multiple traumas due to various causes.

Of the 609 patients, the majority (56.2\%) were boys, being the median ages of 36 months, $44.7 \%$ infants and $26 \%$ aged up 11 years. The mean length of stay in hospital was $6.9 \pm 5.5$ days. These data are similar to those in previous studies $^{6-9}$

Schoolars' hospitalisation in the PICU was longer. In our study, the mean length of hospitalisation for those diagnosed with pneumonia was 22 days. A study conducted by Veras et al $^{9}$ reported that the average length of hospitalisation for pneumonia in children was 6.2 days, but this time increased to 22 days in children discharged from the PICU. After the first year of high intensive care, the risk of death is 3.4 times higher than the general population and the risk of mortality is high up to the fourth year after the discharge of the PICU. Age and the existence of preexisting serious illness are factors that influence the mortality rate and quality of life after discharge ${ }^{11,12}$.

The annual average admissions identified in the study are similar to those observed by Einloft et $\mathrm{al}^{7}$. The uniform monthly distribution of hospitalisations during the study may be explained by individual clinical condition that need or don't need intensive care, not related to seasonality, except for some diseases as bronchiolitis, chickenpox, and dengue. The study of Lanetzki et al. presented a higher number of hospitalisations in the PICU in April, August, and October ${ }^{13}$.

The PICU/HINSG has six beds, with a mean of 25 patients per month, found in the study period. According to the Ministry of Health, the calculation of the need for beds in a given region and for a given population should take into account the hospital occupancy rate and the average length of hospital admission. The observed mean of hospitalisation is according to other studies; however, due to the small number of available beds, many patients with acute or chronic diseases that have precise indication of PICU are attended in the hospital's infirmary, in mechanical ventilation, use of vasoactive drugs, and monitoring specific of critical care.

The PICU/HINSG adopts clinical protocols and administrative procedures and has a monthly average occupancy rate of $100 \%$, which is higher than the minimum $90 \%$ required ${ }^{14}$ for public investment in intensive care units. Despite the fulfillment of the criteria set by public health policies, the maintenance of the low number of beds affects the assistance and imposes risks of death or permanent damage to patients that atherwise could benefit from the care of paediatric intensive unit.
Most hospitalisations were due to clinical conditions involving respiratory illnesses such as pneumonia, bronchiolitis, and asthma. This finding is similar to the findings of Molina et al. ${ }^{8}$ and Oliveira et al., ${ }^{15}$ who identified between $41.3 \%$ and $49.6 \%$ of hospitalisations for respiratory diseases. On the other hand, Costa et al. ${ }^{6}$ reported a involvement of the respiratory tract in $27.5 \%$ of the cases and in $15.9 \%$ there were surgical causes, in São Luis, Maranhão, Brazil. The prevalence of respiratory diseases such as asthma and respiratory failure was also observed in the Virtual Paediatric Intensive Care System database, that groups information of patients in more than 100 PICUs in USA ${ }^{16}$. Although chronic diseases sequency is growing in Brazil, the occurrence of infectious diseases is still significant.

The hospitalisation of surgical patients $(24.5 \%)$ is justified by the fact that HINSG has an emergency service, being a State reference in paediatric surgery, and by not having a care unit and post-operatively monitoring. This is close to what was found by other authors, including Sfoggia et al. ${ }^{17}$ and Einloft et al. ${ }^{7}$, who found a frequency of surgical admissions of $25.8 \%$ and $20.3 \%$, respectively. Regarding the involvement of organs and systems, Khilnani et al. ${ }^{9}$ and Linhares et al. ${ }^{12}$ reported results similar to those found in our study.

We observed a mortality rate of $15.6 \%$, with no association with age or sex. This percentage is higher than those found by other authors ${ }^{7-13}$, who reported mortality rates ranging from $1.85 \%$ to $7.4 \%$ and with a greater prevalence among infants under 12 months..$^{7-9}$ In contrast, Freire et al. ${ }^{18}$ and Costa et al. ${ }^{6}$ reported mortality rates of $19.2 \%$ and $33.9 \%$, respectively, in the cities of Natal, Rio Grande do Norte, and São Luiz, Maranhão, Brazil. The percentage of mortality differences may be related mainly to the indications of hospitalisation in the PICU; to the clinical conditions at admission and the high availability of beds and resources to hospitalise patients before clinical deterioration or increased tissue damage.

Additionally, the prevalence of respiratory diseases increases in children attending daycare, which justifies the need for systematic prevention activities. In this study, respiratory diseases affected mainly the children under 5 years old, age group who attend daycare centres ${ }^{20}$. On the other hand, structural inadequacies and human resources are inequalities in health care and suggest the need for adjustments and priorities in the effective implementation of public policies in order to fix deficiencies and minimise respiratory events and their complications ${ }^{21}$.

Infant mortality has declined, though not uniformly, in different regions of Brazil22,23. A nationwide study indicated a reduction in mortality from pneumonia in children of less than 4 years of age, with greater reductions in the south and southeast regions, indicating remaining discrepancies among the different regions of Brazil ${ }^{19}$.

The fact that almost $30 \%$ of patients who stayed in hospital $\leq 24$ hours to progress to death is probably related to the severity of the condition 
of patients admitted to the unit. In a study conducted in a PICU in Rio Grande do Sul, Brazil, covering a period of 16 years, Einloft et al. ${ }^{7}$ noted that the deaths occurring within the first 24 hours of admission ranged from $12 \%$ to $70 \%$ of the total. Thinking about fatal events or those resulting in permanent sequels, interrupting the normal development trajectory and causing great impact on the family, is needed ${ }^{24}$.

The early deaths may be associated with hospitalisations for serious injury or acute infectious diseases, no identification or late diagnosis of the severity of the disease, a slow to start late appropriate therapy, waiting for a critical care bed, and poor quality in the initial treatment or transport of these patients to a referral hospital. All these causes are considered determining factors to the outcome of every seriously ill child admitted to intensive care.

In daily practice, it is observed that the children admitted in very serious condition, requiring mechanical ventilation and vasoactive drugs for more than 48 hours and/or those who require renal therapy are the ones that die the most in the first 48-72 hours, later, after the second week of intensive care. The mortality in these cases usually occurs as a result of infectious complications and/or organic severe dysfunction.

In a cross-sectional study including 32 consecutive PICU admissions, Marcin et al. ${ }^{25}$ noted that most of patients that had a prolonged stay ( $>12$ days) in the unit were young children (45.5 months) with previous admissions in the sector who need long-term care, such as the use of gastrostomy, tracheostomy, dependence on mechanical ventilation and/or parenteral nutrition. Furthermore, this group of patients represented $2.1 \%$ to $8.1 \%$ of all admissions in the PICUs analysed.

Costa et al. ${ }^{6}$ reported that $49.7 \%$ of admissions in São Luiz's, Maranhão, Brazil PICUs patients had comorbidities such as lung diseases, heart diseases, and genetic disorders. The change in the pattern of diseases such as hospitalised victims of violence, cancer, and genetic diseases, can justify the hospital admission of more than 11 days in $18.4 \%$ of cases in our study.

Optimising the use of intensive care beds should take into account the profile of admitted patients, especially those with many comorbidities and permanent sequelae. These patients occupy the beds of a PICU for an extended period, avoinding the rotation of the bed for other children who could benefit from treatment.

Admission of children with chronic medical conditions should be prioritised for intermediate care units or other specific sectors in caring for this patient profile, like measures adopted in early physical rehabilitation, family support, and nutritional support. This type of care brings more benefit to the chronic patient, optimises public expenditure, and improves comprehensive care provided in paediatric intensive care.

Namachivayam et al. ${ }^{26}$ described the profile of children in a reference PICU in Australia in the past three decades and reported a reduction of $13 \%$ in traffic accidents in 1982 to $7 \%$ in 2005 and 2006, due to stricter laws in that country and the implementation of educational measures. This is contrary to what is observed in Brazil, where these patients crowd the PICUs, due to cranial trauma, severe orthopaedic injuries, and politrauma.

It was identified median hospitalisation, due to trauma, of 19 days, and among the most frequent injuries the wound by a firearm was highlighted, especially in adilesants over 10 years old, which is directly related to violence in the State. Oliveira et al. ${ }^{27}$ studied the causes of hospitalisation of children aged 1-4 years in the Unified Health System (SUS) from 1998 to 2007. Official data from DATASUS, and found the external causes as one of the leading causes of morbidity, in all Brazilian regions.

The mean length of stay in hospital of patients of PICU/HINSG draws attention to the need of structuring the care in the hospital. The low turnover of intensive care beds in the hospital is due in part to a lack of semi-intensive care beds. This favours the stay in intensive room of the patient classified as potentially serious, who need non-invasive monitoring after recovery from acute condition of the disease.

The presence of an intermediate unit provides integral care to this patient profile and allows higher turnover of intensive care beds. The low alternation of beds results in the worsening of assistance to a critically ill child, as well as increased public spending on hospital $\operatorname{costs}^{28}$. Thus, technical planning of the intensive care unit includes structuring the service along these lines, being the epidemiological data important to health care and implementation of public policies.

In assessing the outcome of the particular unit patients, one must consider the factors involved, including those related to the patient, such as admission diagnosis and pre-existing diagnoses, unit routines, and other factors as available treatments, social/cultural conducts, and the attitude about prolonged care in the hospital system and the public health care system in general ${ }^{29}$. Thus, the assessment of quality of care in a PICU encompasses the study of the prognosis of these patients in the recovery phase of the critical condition after the discharge from the intensive care unit.

In the context of the field of public health, to reduce the mortality of children under the age of 5 years old remains a global priority. In 2012, 6.6 million children under the age of 5 years old died worldwide; more than half of these deaths were due to diseases that are preventable and treatable through simple and affordable interventions. However, two major challenges must be faced by the international community: the wide disparity in the risk of infant death among countries, and the emerging role of neonatal death as a key component of infant mortality.

In order to reduce mortality in children under 5 years old and infant mortality worldwide, current efforts should continue, and new strategies must be implemented to focus on the prevention of 
neonatal deaths, that shows high proportion of children mortality ${ }^{30}$.

Furthermore, health care conventionally considered the diagnosis, treatment, and prevention of diseases, accidents, and other physical and/or mental disabilities. Public health professionals have to integrate and support the capacity in the definition of Public Health ${ }^{31}$.

The findings of epidemiological studies, as listed in Tables 1 to 3, are an important contribution for the fully improving activities in public health and in the general condition of this population.

\section{REFERENCES}

1. Lago PM, Garros D, Piva JP. Terminalidade e condutas de final de vida em unidades de terapia intensiva pediátrica. Rev Bras Ter Intensiva. 2007;19(3): 359-63. DOI: http:// dx.doi.org/10.1590/S0103-507X2007000 300017

2. Martha VF, Garcia PCR, Piva JP, Einloft PR, Bruno F, Rampon V. Comparação entre dois escores de prognóstico (PRISM e PIM) em unidade de terapia intensiva pediátrica. J Pediatr. 2005; 81(3): 259-64. DOI: http://dx.doi.org/ $10.2223 / 1348$

3. Koliski A, Cat I, Giraldi DJ, Cat ML. Lactato sérico como marcador prognóstico em crianças gravemente doentes. J Pediatr. 2005; 81(4): 287-92. DOI: http://dx.doi.org/10.2223/ JPED. 1364

4. Brasil. Conselho Nacional de Secretários de Saúde (CONASS). Atenção primária e promoção da saúde. Brasília: 2007.

5. Costa MCO, Souza RP. Costa MCO, Souza RP, editores. Semiologia e atenção primária à criança e ao adolescente. In: Costa MCO, Souza RP. Abordagem da criança e do adolescente. Rio de Janeiro: Revinter; 2005; p.76-91.

6. Costa CMS, Prazeres JS, Rolim JM, Forte SR, De Aquino DMC. Perfil epidemiológico dos pacientes internados em uma Unidade de Terapia Intensiva pediátrica, São Luiz, MA. Rev Hosp Universitário. 2009;10(3): 61-66.

7. Einloft PR, Garcia PC, Piva JP, Bruno F, Kipper DJ, Fiori RM. Perfil epidemiológico de dezesseis anos de uma unidade de terapia intensiva pediátrica. Rev Saúde Pública. 2002; 36(6): 728-73. DOI: http://dx.doi.org/10.1590/ S0034-89102002000700011

8. Molina RCM, Marcon SS, Uchimura TT, Lopes EP. Caracterização das internações em uma unidade de terapia intensiva pediátrica, de um hospital-escola da região sul do Brasil. Ciênc Cuid Saúde. 2008; 7(1): 112-20. DOI: http:// dx.doi.org/10.4025/cienccuidsaude.v7i0.6581

9. Khilnani P, Sarma D, Singh R, Uttam R, Rajdev S, Makkar A, et al. Demographic profile and outcome analysis of a tertiary level pediatric intensive care unit. Indian J Pediatr. 2004;71(7): 587-91. DOI: http://dx.doi.org/ 10.1007/BF02724117

10. Veras TN, Sandim G, Mundim K, Petrauskas R, Cardoso G, D’Agostin J. Perfil epidemiológico
In conclusion, there was a predominance of hospitalisations in the infant age group $(44.7 \%)$, followed by children older than 10 years, reflecting the consequences of external injuries and violence. Clinical diseases (39.9\%) were predominant, with emphasis on respiratory conditions such as pneumonia, bronchiolitis, and asthma, and surgical causes were observed in $24.5 \%$ of the sample. The average hospital stay in the PICU was one week, and the mortality rate was $15.6 \%$, with one third of the deaths recorded within the first 72 hours of hospitalisation.

de pacientes pediátricos internados com pneumonia. Sci Med. 2010; 20(4): 277-81.

11. Gunning K, Rowan K. ABC of intensive care: Outcome data and scoring systems. Clin Rev. 1999;319(7204): 241-44.

12. Linhares DG, Siqueira JE, Previdelli ITS. Limitação do suporte de vida em unidade de terapia intensiva pediátrica. Rev Bioética. 2013; 21(2): 291-97.

13. Lanetzki CS, Oliveira CA, Bass LM, Abramovici $S$, Troster EJ. The epidemiological profile of Pediatric Intensive Care Center at Hospital Israelita Albert Einstein. Einstein. 2012;10(1):16-21. DOI: http://dx.doi.org/ 10.1590/S1679-45082012000100005

14. Ministério da Saúde. Portaria no 2.395, de 11 de outubro de 2011. Organiza o componente hospitalar da Rede de Atenção às Urgências no âmbito do Sistema Único de Saúde (SUS). Diário Oficial da União. 13 out 2011; Seção 1.

15. Oliveira BRG, Viera CS, Furtado MCC, Mello DF, Lima RAG. Perfil de morbidade de crianças hospitalizadas em um hospital público: implicações para a enfermagem. Rev Bras Enferm. 2012;65(4): 586-93. DOI: http:// dx.doi.org/10.1590/S0034-71672012 000400006

16. Wetzel RC, Sachedeva R, Rice TB. Are all ICUs the same? Pediatr Anesth. 2011; 21(7): 7 87-93. DOI: http://dx.doi.org/10.1111/ j.1460-9592.2011.03595.x

17. Sfoggia A, Fontela PS, Moraes A, Silva F, Sober RB, Noer RB, et al. A sedação e analgesia de crianças submetidas à ventilação mecânica estariam sendo superestimadas? J Pediatr. 2003;79(4): 343-48. DOI: http://dx.doi.org/ 10.1111/j.1460-9592.2011.03595.x

18. Freire ILS, Torres GV, Menescal PJTJ, Feitosa JID. Perfil epidemiológico das crianças internadas em uma unidade de terapia intensiva pediátrica. In: Congresso Brasileiro de Enfermagem 2009. Associação Brasileira de Enfermagem. Fortaleza: 2009; p. 8175-76.

19. Rodrigues FE, Tatto RB, Vauchinski L, Leães LM, Rodrigues MM, Rodrigues VB, et al. Mortalidade por pneumonia em crianças brasileiras até 4 anos de idade. J Pediatr. 2011; 87(2): 111-14. DOI: http://dx.doi.org/10.1590/S002175572011000200005

20. Veríssimo MDLÓR. Ocorrência de agravos respiratórios em creches universitárias e municipais na cidade de São Paulo. Rev Bras 
Crescimento e Desenv Hum. 2005; 15(2): 1-12.

21. Freitas CBD. Estrutura do Atendimento à Saúde da Criança no Brasil. Rev Bras Crescimento Desenv Hum. 1993; 3(1): 64-76.

22. Frias PG, Szwarcwald CL, Souza Junior PRB, Almeida WS, Lira PIC. Correção de informações vitais: estimação da mortalidade infantil, Brasil, 2000-2009. Rev Saúde Pública. 2013;47(6): 1048-58. DOI: http://dx.doi.org/10.1590/ S0034-8910.2013047004839

23. Mújica OJ, Vázquez E, Duarte EC, CortezEscalante JJ, Molina J, Silva Junior JB. Socioeconomic inequalities and mortality trends in BRICS, 1990-2010. Bull World Health Organ. 2014;92(6): 405-12. DOI: http://dx.doi.org/ 10.2471/BLT.13.127977

24. Bomfim AC, Bastos AC, Carvalho AMA. A família em situações disruptivas provocadas por hospitalização. Rev Bras Crescimento Desenv Hum. 2007; (1):84-94.

25. Marcin JP, Slonim AD, Pollack MM, Ruttimann UE. Long-stay patients in the pediatric intensive care unit. Crit Care Med. 2001; 27(3): 652-57.

26. Namachivayam $P$, Shann $F$, Shekerdemian $L$, Taylor A, Sloten IV, Delzoppo C, et al. Three decades of pediatric intensive care: who was admitted, what happened in intensive care, and what happened afterward. Pediatr Crit Care Med. 2010;11(5): 549-55. DOI: http:// dx.doi.org/10.1097/PCC.0b013e3181ce7427

27. Oliveira BRG, Viera CS, Collet N, Lima RAG. Causas de hospitalização no SUS de crianças de zero a quatro anos no Brasil. Rev Bras Epidemiol. 2010;13(2):268-77. DOI: http:// dx. doi . org/10.1590/S1415-790X 2010000200009

28. Nogueira LS, Sousa RMC, Padilha KG, Koike KM. Características clínicas e gravidade de pacientes internados em UTIS públicas e privadas. Texto Contexto Enferm. 2012; 21(1): 59-67.

29. Butt W. Desfecho após a alta da unidade de terapia intensiva pediátrica. J Pediatr. 2012; 88(1):1-3. DOI: http://dx.doi.org/10.2223/ JPED. 2165

30. Atrash HK. Childhood mortality: still a global priority. J Hum Growth Dev. 2013; 23(3): 257-60.

31. Atrash HK, Carpentier R. The evolving role of public health in the delivery of health care. Rev Bras Crescimento Desenvolv Hum. 2012; 22(3): 396-9.

\section{Resumo}

Introdução: As Unidades de Cuidados Intensivos Pediátricos apresentaram importantes avanços tecnológicos e de assistência a partir da década de 80, o que tornou favorável a evolução e prognóstico de crianças gravemente doentes em todo o mundo. Objetivo: Identificar perfil epidemiológico e evoluções clínicas de crianças e adolescentes internados em uma Unidade de Cuidados Intensivos Pediátricos de Hospital referência de Vitória-ES. Método: Estudo descritivo e retrospectivo realizado na Unidade de Cuidados Intensivos Pediátricos do Hospital Infantil Nossa Senhora da Glória, Vitória-ES. Idade, sexo, diagnóstico de internação, evolução para alta/óbito e tempo de internação foram obtidos no Setor de Arquivo Médico e Estatística do hospital, entre 2011 e 2012. Para a análise descritiva, as variáveis categóricas foram expressas como frequências absolutas e percentuais e as variáveis contínuas, apresentadas em média e desvio-padrão. Para comparações foram utilizados os testes qui-quadrado de Pearson, teste de Fisher e teste t de Student, considerados estatisticamente significativos valores de $p<0,05$, intervalo de confiança de 95. Resultados: Dos 609 pacientes analisados, 342 (56,2\%) eram do sexo masculino

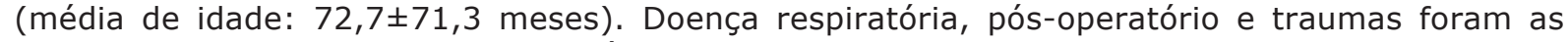
principais causas de internação. A média de internação foi de 6,9 \pm 5,5 dias; $514(84,4 \%)$ receberam alta hospitalar, $95(15,6 \%)$ evoluíram para o óbito e desses, $53(55,7 \%)$ com menos de 72 horas de hospitalização. Conclusão: A maioria dos internados apresentou idade inferior a 2 anos. As principais causas de internação foram doenças respiratórias (pneumonia, broquiolite e asma), sepse e traumatismo craniano foram as principais causas de internação, sendo uma importante causa o trauma motivado pela violência. A média de internação nessa unidade foi de uma semana e a taxa de mortalidade foi de $15,6 \%$, com $1 / 3$ dos óbitos registrados nas primeiras $72 \mathrm{~h}$ de internação.

Palavras-chave: unidades de terapia intensiva pediátrica, perfil de saúde, criança. 